\title{
Review of Foundations of Adult and Continuing Education
}

Cristine Smith, University of Massachusetts

Faculty of adult and continuing education (ACE), take notice: there's a new textbook in town.

While there are plenty of textbooks for graduate students on adult education, adult learning, and continuing education theory and practice, the new Foundations of Adult and Continuing Education by Ross-Gordon, Rose, and Kasworm (2017) takes a slightly different tack. The authors have designed it as a textbook about the field of adult education as a profession. Their purpose is to acquaint "practitioners and emerging scholars alike with the historical and contemporary context of the field and its place in society" (p. vii). Rather than start with adult learning theories, the book's first four (out of 12) chapters focus instead on contemporary definitions, forms, and types of adult education; the changing nature of participation and participants in ACE; the development and role of an adult educator as a teacher, administrator, mentor, and professional in the field; and the ACE profession and field, historically, present-day, and trends for the future. Since the book's focus is adult education in the United States, it may be most useful for those graduate students who intend to work in the United States while still providing background on the field for those whose goal is to work in the adult education profession in other countries.

The middle third of the book focuses on the traditional "foundations" of the field: philosophy in relation to adult education; a history of formal (higher education), non-formal, vocational, social justice, and basic or literacy education for adult students in the United States; the adult learner and perspectives on learning, such as andragogy, selfdirected learning, transformational, cognition, spiritual, and critical reflection; and the role of policies and politics in ACE. Of particular value to new graduate students is the chapter on philosophy, which defines (rather than assuming knowledge of) key terms about 
knowledge, including ontology, epistemology, and phenomenology, and various philosophical orientations in relation to adult education, such as idealism, realism, pragmatism, existentialism, and postmodernism. In fact, most of this chapter would be useful to any beginning-level graduate student in education or the social sciences.

The final third of the book then steps into specific contexts related to adult and continuing education in the United States. One chapter focuses on technology as a tool for and in adult education, with a short discussion of technology, neuroscience and adult learning, and a longer section on designing ACE programs that effectively integrate technology. Another chapter focuses on the variety of targeted opportunities for populations of adult learners through instruction at work, post-secondary institutions, literacy and English language programs, and the military. The following chapter continues this thread but focused on adult education delivery through faith-based, cultural, health-oriented, democratic and community development, social change, and social justice orientations and purposes. Finally, the book ends with a chapter on trends, recent changes, and future directions for adult education, including adult learner cognition, motivation and participation; diversity; technology; quality and standards; and lifelong learning. While it refers to and summarizes issues discussed in the previous chapters, it could also serve as an introductory chapter to key issues in the field during an adult education graduate course.

As the authors note, although the book uses the term "foundations" in its title, this book is better described as a look at philosophy, history, psychology, and policy as "frameworks for understanding the purpose and structure of adult and continuing education" (p. 384). Either way, the book is comprehensive, well-organized, upto-date, easy to read, and rich in its discussions of theory and practice, past and present, abstract and concrete. The middle section, particularly the two chapters on (1) philosophy and (2) the adult learner, could easily be used separately in a graduate class on adult learning theory and practice that might draw students from any field that provides information or educational services to improve adults' health, legal, financial, or technology literacy. Used in its entirety, it would serve as a thorough and broad introduction to the field, its research, its profession, and its learners in the United States. I heartily recommend this book as a primary text for introductory adult and continuing education graduate courses, either face-to-face or online, especially for programs where students see themselves as future policymakers or administrators. 